\title{
SIMULATED MIGRATION OF EUROPEAN SILVER EEL; SWIM CAPACITY AND COST OF TRANSPORT
}

\author{
Guido Van den Thillart \\ Institute Biology, Leiden University, POB 9516, 2300RA Leiden, The Netherlands., \\ g.van.den.thillart@biology.leidenuniv.nl \\ Arjan Palstra \\ Institute Biology, Leiden University, POB 9516, 2300RA Leiden, The Netherlands. \\ Vincent Van Ginneken \\ Institute Biology, Leiden University, POB 9516, 2300RA Leiden, The Netherlands.
}

Follow this and additional works at: https://jmstt.ntou.edu.tw/journal

Part of the Aquaculture and Fisheries Commons

\section{Recommended Citation}

Thillart, Guido Van den; Palstra, Arjan; and Ginneken, Vincent Van (2007) "SIMULATED MIGRATION OF EUROPEAN SILVER EEL; SWIM CAPACITY AND COST OF TRANSPORT," Journal of Marine Science and Technology. Vol. 15: Iss. 5, Article 1.

DOI: $10.51400 / 2709-6998.2053$

Available at: https://jmstt.ntou.edu.tw/journal/vol15/iss5/1

This Research Article is brought to you for free and open access by Journal of Marine Science and Technology. It has been accepted for inclusion in Journal of Marine Science and Technology by an authorized editor of Journal of Marine Science and Technology. 
SIMULATED MIGRATION OF EUROPEAN SILVER EEL; SWIM CAPACITY AND COST OF TRANSPORT

Acknowledgements

Funded by grants from EU (EELREP \#Q5RS2001-01836), and STW- Dutch technology foundation (LBI66.4199). 


\title{
SIMULATED MIGRATION OF EUROPEAN SILVER EEL; SWIM CAPACITY AND COST OF TRANSPORT
}

\author{
Guido Van den Thillart*, Arjan Palstra*, and Vincent Van Ginneken*
}

\begin{abstract}
Key words: european eel, cost of transport, migration, endurance swimming, maturation, oocyte growth, lipid, silvering, swimbladder parasite.
\end{abstract}

\begin{abstract}
An important aspect of the reproduction of European silver eels is the huge distance ( $c a 6000-\mathrm{km}$ ) they have to swim to reach their spawning grounds. So, obviously endurance swimming is a major requirement for successful reproduction. As migrating eels don't feed, two major questions should be asked: 1) what are the energy costs to cross the Atlantic Ocean, 2) How much fat do eels need to cover the expenses. From swim tunnel experiments run for days till even 6 months we could determine the cost of transport (COT): $0.5 \mathrm{~kJ}$ $\mathrm{km}^{-1} \mathrm{~kg}^{-1}$. This amount is about 5 times lower than COT values of salmonids of similar size, also those low costs allow eels to spend only $60 \mathrm{~g}$ fat $/ \mathrm{kg}$ for the whole journey. As eels have around $200 \mathrm{~g} \mathrm{fat} / \mathrm{kg}$, there is more than enough left after reaching the spawning site for gonad development and spawning behavior. Although the swim endurance of eels is impressive, large female eels $(1-2 \mathrm{~kg}, 70-80 \mathrm{~cm})$ can swim for prolonged periods not much faster than $1.6 \mathrm{BL} / \mathrm{s}$, with their best performance around $0.8 \mathrm{BL} / \mathrm{s}$.

When leaving the European West coast, silver eels are still in a prepubertal condition, suggesting that somewhere during their journey sexual maturation needs to be activated. We hypothesized that swimming might be such a trigger. Indeed we observed significant changes in female eels already after several weeks of swimming. We observed a significant increase of eye size, gonad weight and oocyte diameter, the latter mainly due to the deposition of many lipid droplets. However, no further development of oocyte size was observed when the eels continued swimming. The mechanism behind the oocyte growth might be connected to stimulation of lipid mobilisation required for swimming. Lipid stores are not only important for long distance swimming, but also for gonad growth and gamete production. Based on the lipid content of eggs, we estimated that around $60 \mathrm{~g}$ fat $/ \mathrm{kg}$ eel is required for reproduction. Combined with the requirement for swimming, total lipid content of succesful spawners must be at least $12 \%$, i.e. $120 \mathrm{~g}$ fat $/ \mathrm{kg}$.
\end{abstract}

Author for Correspondence: Guido Van den Thillart.

E-mail: g.van.den.thillart@biology.leidenuniv.nl.

*Institute Biology, Leiden University, POB 9516, 2300RA Leiden, The Netherlands.

\section{INTRODUCTION}

\section{Migration}

An important aspect of the reproduction of European silver eels is the huge distance they have to swim to reach their spawning grounds. After leaving the West European coast they still have to swim $5000-6000 \mathrm{~km}$ to the Sargasso Sea, the assumed spawning site. So, obviously long term swimming capacity is a major requirement for successful reproduction. Migrating eels don't feed; therefore they rely completely on fat stores for their energy. Fat stores are up to $30 \%$ of their body weight. Silver eels must swim across the Atlantic Ocean in about 5-6 months, this is the difference between the time they leave and the time the first larvae are observed in the Sargasso Sea. From the time needed to cross the ocean in combination with the distance a mean swimming speed of $0.4 \mathrm{~m} / \mathrm{s}$ can be calculated. The long distance migration suggests 2 major questions: 1) Do they have enough energy reserves? 2) Are they built to swim long distances? To know whether they have enough energy for successful reproduction, it is important to know the energy consumption during long term swimming as well as the amount of the initial fat stores.

Thus far long term swimming was, to our knowledge, never carried out before with fishes. This requires the construction of special equipment, such as available at the Institute of Biology Leiden. Long term swimming may be a much heavier burden to animals than short term swimming, since under those conditions the experimental animals do not have the opportunity to recover. This obviously causes a constant stress, which makes them sensitive to otherwise harmless viral and bacterial infections. Thus far nothing was known about the swimming and endurance capacity of eels. Swimming speeds, endurance capacity, and oxygen consumption rates have to be measured to answer the above questions.

European eels migrate great distances to reach their spawning sites. As silver eels they leave the 
European West Coast in the fall and are supposed to reach the Sargasso Sea after about 6 months [69]. The distance they have to cover is about $6,000-\mathrm{km}$, which means for an $80-\mathrm{cm}$ female eel $(1-\mathrm{kg})$ a swimming speed of about $0.5 \mathrm{BL} / \mathrm{s}$. Characteristic for silver eels is that they stop feeding when they start migrating down the rivers between August and October (Dutch situation). Although they leave for the spawning site to reproduce, they are still immature at that time. So, the gonads have to develop during or after their migration. Eels have much fat as energy stores, however it was not known how much is required for crossing the Atlantic. For their long-distance migration to the Sargasso Sea the energy reserves may easily become critical particularly since the fat percentage varies largely [66, 67]. An estimation of the energy required to cover the distance was presented in a recent paper. Based on the oxygen consumption rates during a 10-day swim trial, the equivalent fat consumption extrapolated to $6,000-\mathrm{km}$ was 120 $\mathrm{g}$ per $\mathrm{kg}$ or $40 \%$ of the initial fat reserve [77]. More extensive data were obtained from intermediate $(1,000-$ $\mathrm{km})$ to even long term $(5,500-\mathrm{km})$ swim trials $[78,80]$, that showed the high endurance and low cost of swimming of the European eel.

Johannes Schmidt [56] found the smallest eel larvae (leptocephali) of the European eel (Anguilla anguilla $L$.) at the beginning of the previous century near the Sargasso Sea and the largest near the European coast [58]. This is the only evidence to date that locates the spawning grounds in the Sargasso Sea (neither eggs nor mature adults have ever been found in this area). For Schmidt's theory to be supported, the following three conditions must be met: a) Adult European eels must be able cover a distance of $6,000-\mathrm{km}$ in a fasting state, implying that migrating eel must have sufficient energy reserves to cover this enormous distance [72]. b) Mature European eels and fertilized eggs must be found in the Sargasso Sea. c) Eel larvae must be shown to migrate towards the European coasts. Questions (a) and (b) are still not resolved. As for condition (c), the most recent observations on larval migration patterns were published by McCleave et al. [37]. They clearly indicate that the larvae are transported from the Sargasso Sea to the European Coast. However, not resolved are questions concerning the large variation in age [2] and the genetic make up [93] of glass eels. These authors suggest the existence of more than one spawning site. To test condition (b), the group of Tesch [56] tried, so far without success, to catch adult eels in the Sargasso. Until now there are only two reports of incidentally caught silver eels (A. anguilla) in the open Atlantic [6, 28]. Concerning condition (a), Tucker [72] expressed severe doubts whether the European eel would be able to swim across the ocean and suggested that all Euro- pean eels are the offspring of the American eel. Tucker's 'new solution to the Atlantic eel problem' provoked a long debate $[17,19]$ and was finally rejected when a distinction could be made between the two Atlantic eel species based on allozymes [91], enzymes [15], mitochondrial DNA [3, 4, 68] and genomic DNA [45].

\section{Environmental factors}

Three former studies investigated the influence of the swim bladder parasite $A$. crassus on swimming of eel. Barni et al. [5] found lower cruise speeds for infected eels. Sprengel \& Luchtenberg [64] found a reduction of maximum swimming speed. Recently, Münderle et al. [42] did not find any negative relation between swimming activity of eels and intensity of $A$. crassus infection, at least in the short-term. However, studies were performed with elvers and not with silver eels. Only results on swimming of silver eels should be extrapolated to migration to the Sargasso Sea. Oxygen consumption has not been measured in these studies making it impossible to judge swim efficiency and cost of transport of infected eels. A new factor, that has not received much attention to date, is the world-wide occurrence of eel viruses [79, 80]. Viruses are known to affect blood-forming tissues in fish, and typically become virulent during stress [94]. In salmon for example, Infectious Haematopoietic Necrosis Virus (IHNV) and Viral Hemorrhagic Septicemia Virus (VHSV), both rhabdoviruses, can affect haematopoietic tissues, leading to severe anemia [94]. For eels, long-term migration can certainly be considered as a major stressful event. Therefore, one may assume that an outbreak of a virus infection in infected individuals could take place during this journey.

As eels have high fat levels (up to $30 \%$ ), particularly when they undergo silvering, they accumulate lipophylic compounds from their environment. Eels have been even mentioned as suitable bio-indicators for the occurrence of PCBs $[83,84]$. Of the different compounds the highest levels are always the PCBs (polychlor bi-phenyl), some of which are endocrine disruptors and some are interfering with gene-transcription factors [55], and some are even direct toxic. The summated effect is in general expressed in TEQ (dioxin toxicity equivalent quantity), however it is rather unknown till what extent the effect holds for different species (species specific effects), and how they could interfere with the different processes of animals. Especially the effect on spawning migration could be complex as well as highly significant. Toxicity may cause major damage to liver and kidneys, both organs are important during migration. The liver plays an important role in metabolite homeostasis, detoxification, and 
in the production of vitellogenin during maturation. The kidney is important for excretion of wastes and control of all ions except for $\mathrm{Na}^{+}$and $\mathrm{Cl}^{-}$. Probably the worst effect of dioxin-like compounds will be on maturation and embryonic development. These compounds have been shown to have adverse effects on fertility in fish [65] and amphibians [31]) but also to disrupt mammalian oocyte maturation and follicle physiology in every species studied [55]. Recently we showed that embryonic development time is inversely correlated with dioxin equivalent toxicity values, mainly based PCB content $[48,51]$. Significant effects were observed at levels of $1 \mathrm{ng} / \mathrm{kg}$ gonad, which are 4 fold below the allowable consumption norm.

\section{SWIM CAPACITY}

\section{Swim tunnel}

The principle of the Blazka swim-tunnel was explained in earlier publications $[9,63,76]$, but flow characteristics of a Blazka-type swim-tunnel were to our knowledge never described before. In a recent study we applied the very accurate Laser-Doppler system to demonstrate the homogeneity of the flow in the swim tunnels [75]. The actual flow in a 2-m long swim tunnel was measured at different cross-sections and at different distances from the wall (Figure 1). A linear relationship was observed between the number of revolutions per minute and the measured water velocity. The linearity existed up to $0.9 \mathrm{~m} / \mathrm{s}$. The flow between $40-\mathrm{mm}$ from the wall to the centre stayed within a few percent of the set point. So, fish with a width of $>40-\mathrm{mm}$ can not swim in the boundary layer. The eels used in this study needed an even wider space because of the amplitude of their tail beat. Furthermore we observed that that the head of swimming eels remained between 50 and 100$\mathrm{mm}$ from the wall. Figure 2 shows data of 5 eels swimming 95 days at a swim speed of $0.5 \mathrm{BL} / \mathrm{s}$, thus corresponding to a distance of $2,850-\mathrm{km}$.

\section{Swim fitness}

Swim fitness could be determined in a single day protocol, using the above described swim tunnel [50]. Eels swam 2 hours at each speed from 0.5 to $1.0 \mathrm{~m} / \mathrm{s}$ in steps of $0.1 \mathrm{~m} / \mathrm{s}$. At each speed the oxygen consumption was measured continuously for $90 \mathrm{~min}$. The aerobic maximal speed was interpolated according to the method of Brett [14]. From the data important fitness parameters were calculated: critical swim speed (CSS), optimal swim speed (OSS), and the cost of transport (COT). The data are listed in Table 1 and 2. The most remarkable result is that the COT and the OSS values were almost the same for all 4 groups of female eels tested. Highest critical swim speeds for eels of about $80 \mathrm{~cm}$ were found at $1.64 \mathrm{BL} / \mathrm{s}$ which is low compared to other fish species. The optimum swim speeds, i.e. the speed where the oxygen consumption per $\mathrm{km}$ is the lowest, were found $0.61-0.67 \mathrm{~m} / \mathrm{s}$, and rather similar for a wide size range. COT was similar for all eels; all around 45 $\mathrm{mg} / \mathrm{kg} / \mathrm{km}$. The optimum swim speed was higher than the generally assumed cruise speed of $0.5 \mathrm{BL} / \mathrm{s}$. This would imply that female eels may reach the Sargasso Sea within 3.5 months instead of 6 months [69]. The same results were obtained when the eels were swum for $12 \mathrm{~h}$ at each speed. Figure 3 shows that there was no difference between the speed test (2-h runs) and the endurance test (12-h runs) indicating that eels are very good sustained swimmers.

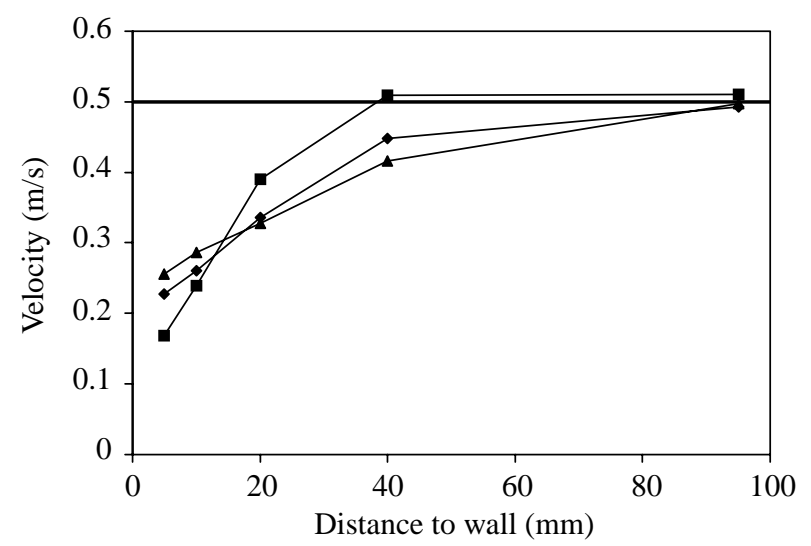

Fig. 1. The velocity profile of a $2-\mathrm{m}$ swim tunnel (127- $\mathrm{L}, 30-\mathrm{cm}$ diameter) from the wall towards the center of the inner tube of the swim tunnel. The flow was measured by a Laser-Doppler system at three cross-sections from the inflow site: $\square 110-\mathrm{mm}, \diamond \mathbf{6 1 0}$ $\mathrm{mm}$, and $\triangle 1100-\mathrm{mm}$. At each cross-section the flow was measured at 5 distances from the wall: $5,10,20,40$ and $95-\mathrm{mm}$. The water velocity at the center of the inner tube was $0.5 \mathrm{~m} / \mathrm{s}$.

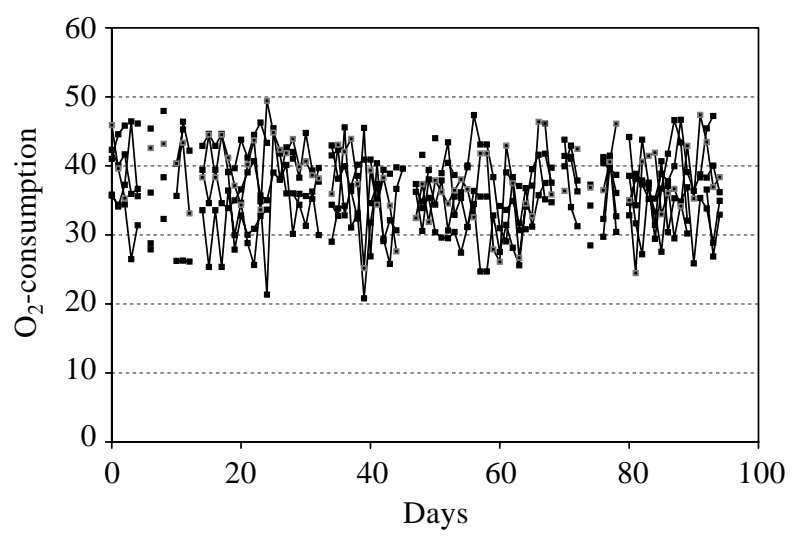

Fig. 2. The oxygen consumption ( $\left(\mathrm{mg} \mathrm{O}_{2} \cdot \mathrm{kg}^{-1} \cdot \mathrm{h}^{-1}\right)$ rates of 5 adult eels $(73 \pm 21 \mathrm{~cm}, 920 \pm 64 \mathrm{~g})$. The eels were swimming continuously at $0.5 \mathrm{BL} / \mathrm{sec}$ and at $19^{\circ} \mathrm{C}$ during a period of 95 days. 
Table 1. Data of experimental eels used for fitness tests. The tests included a stepwise increase in swimming speed starting at $0.5 \mathrm{BL} / \mathrm{s}$ and incrementing with $0.1 \mathrm{BL} / \mathrm{s}$. n: number experimental animals; status: yellow/silver; length $(\mathrm{cm}) \pm \mathrm{SD}$; weight $(\mathrm{g}) \pm \mathrm{SD}$; salinity $(\mathrm{sal})$ : fresh $(\mathrm{FW})$ or sea water $(\mathrm{SW})$; temp: water temperature $\left({ }^{\circ} \mathrm{C}\right)$.

\begin{tabular}{lcccccccc}
\hline Origin & $\mathrm{N}$ & Status & \multicolumn{2}{c}{$\mathrm{L}(\mathrm{cm})$} & \multicolumn{2}{c}{$\mathrm{W}(\mathrm{g})$} & $\mathrm{Sal}$ & Temp \\
& & & Mean & Sd & Mean & Sd & & \\
\hline Royaal & 42 & $\mathrm{y}$ & 67.7 & 4.6 & 673 & 171 & $\mathrm{SW}$ & 18 \\
Lake balaton & 81 & $\mathrm{y} / \mathrm{s}$ & 66.4 & 6.3 & 464 & 146 & FW & 18 \\
Lake grevelingen & 19 & $\mathrm{~s}$ & 78.8 & 5.1 & 949 & 156 & SW & 18 \\
Loire river & 20 & $\mathrm{~s}$ & 82.4 & 6.4 & 1018 & 253 & FW & 18 \\
\hline
\end{tabular}

Table 2. Fitness parameters (average \pm standard deviation) of eels from different locations. Data and conditions of the eels are given in table $1 . \mathrm{CSS}=$ critical swimming speed in $\mathrm{m} / \mathrm{s}(\mathrm{x})$ with corresponding oxygen consumption in $\mathrm{mg} \mathrm{O}_{2} / \mathrm{kg} / \mathrm{h}(\mathrm{y}) . \mathrm{VO}_{2}$ rest is the oxygen consumption in rest in $\mathrm{mg} \mathrm{O}_{2} / \mathrm{kg} / \mathrm{h}$. OSS = optimal swimming speed (at lowest COT; COT = cost of transport in $\mathrm{mg} \mathrm{O}_{2} / \mathrm{kg} / \mathrm{km}$ ).

\begin{tabular}{|c|c|c|c|c|c|c|c|c|c|c|}
\hline & \multicolumn{2}{|c|}{$\begin{array}{c}\mathrm{CSSx} \\
\mathrm{m} / \mathrm{s}\end{array}$} & \multicolumn{2}{|c|}{$\begin{array}{c}\mathrm{CSSy} \\
\mathrm{mgO}_{2} / \mathrm{kg} / \mathrm{h}\end{array}$} & \multicolumn{2}{|c|}{$\begin{array}{l}\mathrm{VO}_{2}(\text { rest }) \\
\mathrm{mgO}_{2} / \mathrm{kg} / \mathrm{h}\end{array}$} & \multicolumn{2}{|c|}{$\begin{array}{c}\mathrm{OSSx} \\
\mathrm{m} / \mathrm{s}\end{array}$} & \multicolumn{2}{|c|}{$\begin{array}{c}\mathrm{COT} \\
\mathrm{mgO}_{2} / \mathrm{kg} / \mathrm{km}\end{array}$} \\
\hline & Mean & $\mathrm{Sd}$ & Mean & $\mathrm{Sd}$ & Mean & $\mathrm{Sd}$ & Mean & $\mathrm{Sd}$ & Mean & $\mathrm{Sd}$ \\
\hline Farm & 0.77 & 0.08 & 135 & 19 & 36 & 5 & 0.67 & 0.15 & 45 & 7 \\
\hline Balaton & 0.67 & 0.14 & 144 & 44 & 39 & 9 & 0.65 & 0.14 & 45 & 12 \\
\hline Grevelingen & 0.71 & 0.14 & 152 & 39 & 35 & 8 & 0.65 & 0.15 & 44 & 17 \\
\hline Loire & 0.66 & 0.18 & 141 & 35 & 43 & 13 & 0.61 & 0.05 & 44 & 11 \\
\hline
\end{tabular}

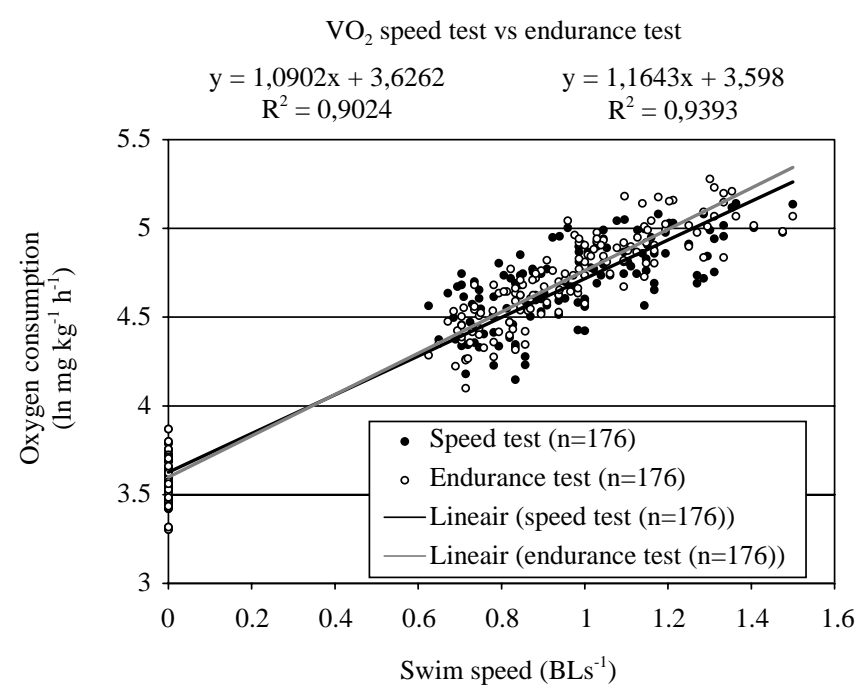

Fig. 3. Data from $2 \mathrm{~h}$ and $12 \mathrm{~h}$ speed test of farmed eels. No difference was observed between the curves for eels in both swim protocols.

\section{Swim bladder parasites}

Infection with the swim-bladder parasite Anguillicola crassus is suggested as one of the causes of the collapse of eel populations worldwide. This nematode has been introduced 20 to 30 years ago from Asia and parasitized in a short time various eel species in differ- ent geographical regions of the world. There are basically two kinds of adverse effects of $A$. crassus infection [32]: 1) energy drain due to sanguivorous activities of the parasites, and 2) mechanical damage of the swimbladder wall. Concerning effect 1 Boon et al. [12] found, that the sanguivorous activities of the parasites decreased the number of circulating erythrocytes. So, highly infected eels will have a lower aerobic performance. Molnár et al. [40] proved that in decreasing oxygen content of the water severely infected eels die first, while uninfected specimens endure the hypoxic condition for a long time. Concerning effect 2 : The migratory activity of the larvae in the swim bladder wall and the direct invasion of the pre-adults and adults in blood vessels, result in extensive damage of the swim bladder wall [40]. Pathological changes include haemorrhages, formation of parasitic nodules, inflammatory cell proliferation, hypertrophy of connective tissue, necrotic areas and oedema. These changes eventually cause substantial thickening of the swim bladder wall [7] and shrinkage of the swim bladder. Thus cured swim bladders are mostly non-functional or even absent, resulting in negative buoyancy.

In a recent study [50] we attempted to estimate the effects of the A. crassus infection on swim capacity and endurance. It was assumed that the parasite weight would impair the endurance mainly by energy drainage. On the other hand damage of the swim-bladder function 
would impair buoyancy control. As the eels without buoyancy control will swim upwards, they must swim at a higher energy cost of transport. Most European eels are moderate to heavy infected by the swim bladder parasite (Figure 4). We selected eighty eels, suffering various degrees of infection, for a swim fitness test. We found that infection and, even more, damage had serious effects on cruising ability and efficiency. Both infection and damage caused higher $\mathrm{O}_{2}$ consumption rates at all swim speeds. Eels with damaged swimbladders had lower optimum swim speed $\left(U_{o p t}\right)$. Infected eels have lower cruise speeds and higher cost of transport. Eels that were not infected, but had a damaged swim bladder from a previous infection, showed similar effects (Figure 5). Almost half of those eels stopped swimming at low speeds $<0.7 \mathrm{~m} / \mathrm{s}$. The effects thus seem to be associated with swim-bladder dysfunction and the resulting loss of neutral buoyancy.

Our results agree with Barni et al. [5] who also
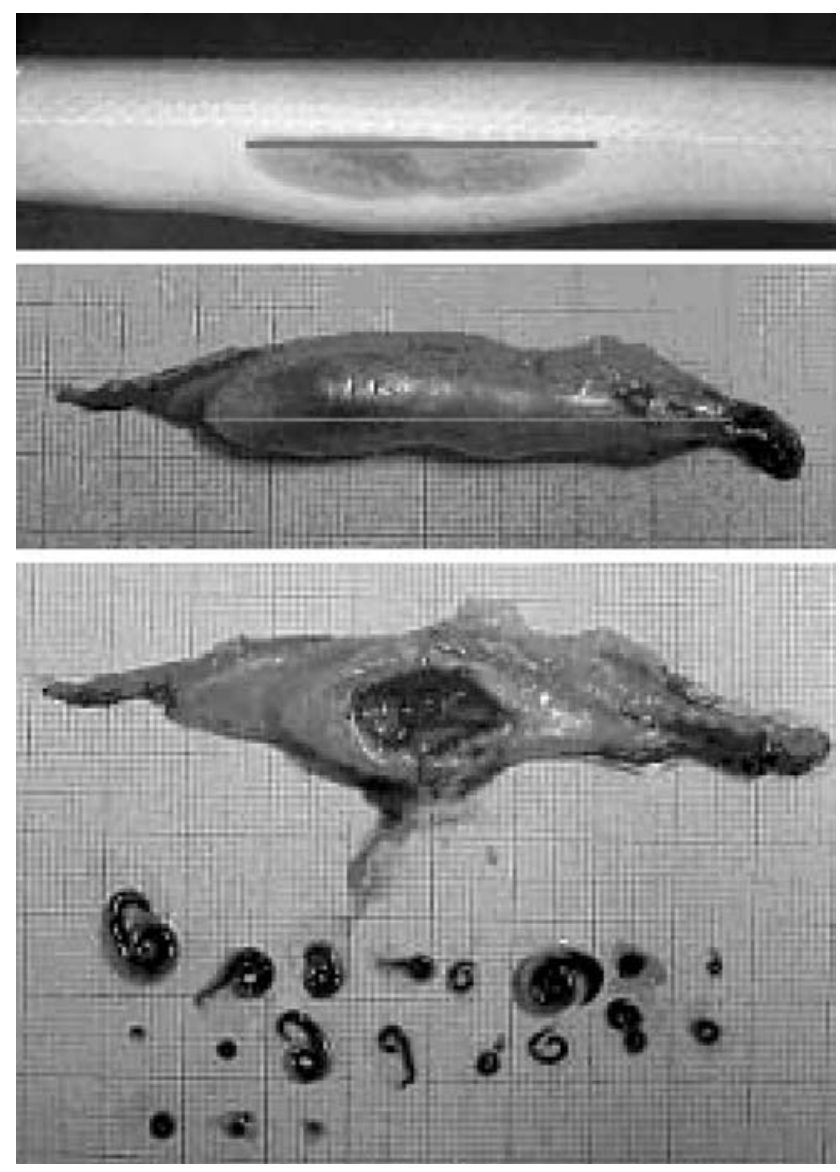

Fig. 4. Since swim bladders shorten as a reaction to infection by the swimbladder parasite (A. crassus). The length of the swim bladder was taken as parameter for damage, which was measured non-invasively by $x$-ray. The weight of the parasites was taken as measure of infection level. found lower cruise speeds for infected eels. However, we did not find a significant reduction of the maximum swimming speed in contrast to Sprengel \& Lüchtenberg [64]. Our results are also in contrast with Münderle $e t$ al. [42], who did not find any negative effect of the infection on the swim capacity of eels. However, their studies were performed with elvers and not with large female silver eels like in our study. Obviously only studies with silver eels should be used to extrapolate infection effects on spawning migration. We found that especially silver eels have significant higher infection levels, possibly related to a pre-silver state of increased food uptake. This leads to the conclusion that infected eels with damaged swim-bladders will likely fail to reach the spawning grounds.

\section{ENDURANCE SWIMMING}

\section{Cost of swimming}

During long-distance migration, animals are likely to maximize the distance covered per given fuel unit, which corresponds to maximizing efficiency. The migration distance of the different eel species varies: the European eel (A. anguilla) 5,500-km [58], the American eel (A. rostrata) 4,000-km [37, 72]; the Australian eel (A. australis) $5,000-\mathrm{km} \mathrm{[33]} \mathrm{and} \mathrm{Japanese} \mathrm{eel} \mathrm{(A.}$ japonica) 4,000-km [71]. So, European eels need to be the most efficient swimmers among eels.

The long-term swim experiments with 5 eels of about $0.9-\mathrm{kg}$ (Figure 2) indicated that eels can be forced to swim under laboratory conditions for a very long
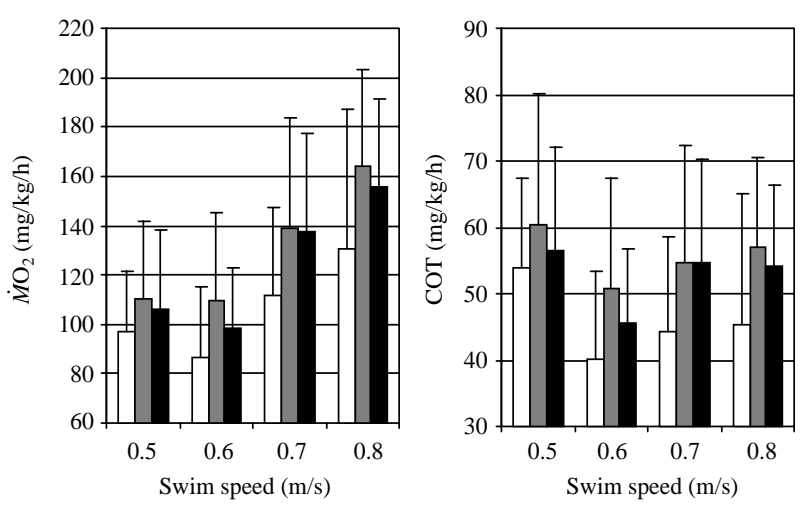

Fig. 5. The effect swim bladder parasite on swim performance of European eel. The oxygen consumption levels $\left(\dot{M} \mathrm{O}_{2}\right)$ and cost of transport (COT) is presented for swim speed of $0.5,0.6,0.7$, and $0.8(\mathrm{~m} / \mathrm{s})$ of healthy eels (white bars), infected eels (grey bars) and damaged eels (black bars). $\dot{M} \mathrm{O}_{2}$ was higher (ANCOVA; $P<0.01$ ) for infected and damaged eels at all swim speeds. The same applied for the COT which was higher for infected and damaged eels at all swim speeds. 
period without resting. Five out of seven eels were able to swim 3 months at $0.5 \mathrm{BL} / \mathrm{s}$, covering a distance of 2,850-km [75]. In literature limited data are available on swimming performance of eels or other anguilliform swimming teleost $[36,90]$. It is suggested that the swimming movement of eel is less efficient than that of for example salmonids $[11,85]$. However, biomechanical efficiency is different from overall efficiency. The latter is expressed in $\mathrm{J} / \mathrm{kg} / \mathrm{km}$, which is for the energy budget of the animal the most relevant measure. Based on a 10 day swim trial with European Silver eel we recently demonstrated that the energy costs of swimming of those eels was extremely low: $0.137 \mathrm{cal}$ $\mathrm{g}^{-1} \mathrm{~km}^{-1}$ [77]. This is 2.4-3.0 times lower than values reported in literature for other species [59]. Eels have a fat content of $10-28 \%$ with a mean of $20 \%$ [66, 67]. Hence, fat is obviously the predominant energy store.

In a recent study we exposed female yellow eels of about $900-\mathrm{g}$ to a 6 months swim trial [78]. The eels swam $5,500-\mathrm{km}$ at a mean swim speed of $0.5 \mathrm{BL} / \mathrm{s}$. The oxygen consumption rates were measured each day. The data shown in Figure 6 indicate that the swimming eels have a 2 -fold higher $\mathrm{O}_{2}$ consumption than the resting eels. Swimming eels have a higher weight loss than the resting eels. The body composition of the 3 eel groups (control, resting, and swimming) was almost identical (Table 3 ). From the $\mathrm{O}_{2}$ consumption the energy consumption can be calculated based on fat combustion data given by Brafield \& Llewellyn ([13]; $19.6 \mathrm{KJ} / \mathrm{O} \mathrm{O}_{2}, 39.5 \mathrm{KJ} / \mathrm{g}$ fat). Thus weight loss for the resting and swimming eels can be converted to energy consumption. The oxygen consumption data on the other hand provide an independent measure for energy consumption. The calculated values for the cost of transport shown in Table 4 are rather close. Those values are some 4-5 fold lower than those obtained for salmonids $[59,78]$. When eels would swim at the same energy consumption rate as salmonids, they would need $300 \mathrm{~g} \mathrm{fat} / \mathrm{kg}$ for crossing the ocean instead of $60-\mathrm{g}$ of fat per $\mathrm{kg}$.

\section{Hydrodynamic performance}

There are various levels of energy conversion in a swimming animal. The overall metabolic efficiency is made up of the efficiencies of various processes, e.g. propeller efficiency (how much momentum is gained by the animal and wasted in the wake) and the muscle efficiency (how many ATP molecules are used per myosin-head cycle). To reduce costs of transport and increase overall metabolic efficiency, all or some of the processes that determine the costs of transport can be optimized. A fish can alter its propeller efficiency by changing its structural design and its motion pattern. Both carangiform and anguilliform swimmers undulate their body, the former with a narrower amplitude envelope than the latter. How the shape of the body undulations affects locomotory efficiency has been estimated using analytical approximations. Lighthill's elongated body theory (EBT) concludes that efficient swimmers should undulate only the most posterior section of their body - in the ideal case only their trailing edge - to maximize propeller efficiency [35, 74]. Daniel's [18]

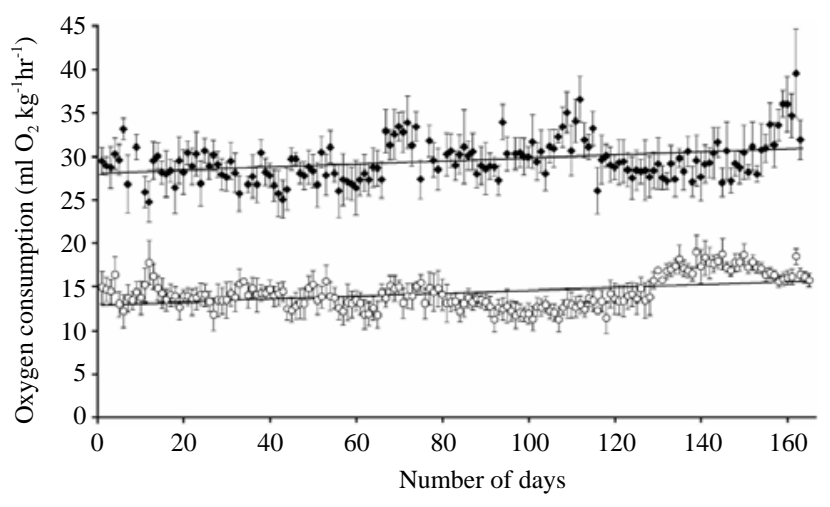

Fig. 6. Oxygen consumption of fasting yellow eels from a hatchery $(860 \pm 81.9 \mathrm{~g}, 73.1 \pm 3.8 \mathrm{~cm})$ during a 6 months period of rest or a 6 months period of continuously swimming at $0.5 \mathrm{BL} / \mathrm{s}$ at 19 ${ }^{\circ} \mathrm{C}$. Regression lines: Rest-group: $Y=0.0326 X+25.294$; Swimgroup: $Y=0.0394 X+54.86$. Diamonds: (swimming), circles (resting). [81]

Table 3. Body-constitution in \% of wet weight of female yellow eels at the start and after 6 months swimming or resting.

\begin{tabular}{lrcrrrr}
\hline & \multicolumn{2}{c}{ Start $(\mathrm{n}=15)$} & \multicolumn{2}{c}{ Awim $(\mathrm{n}=9)$} & \multicolumn{2}{c}{ Rest $(\mathrm{n}=15)$} \\
& Mean & $\pm \mathrm{Sd}$ & Mean & $\pm \mathrm{Sd}$ & Mean & $\pm \mathrm{Sd}$ \\
\hline Fat & 67.9 & 1.9 & 68.1 & 2.5 & 68.1 & 2.2 \\
Protein & 28.2 & 1.8 & 28.3 & 2.2 & 28.0 & 2.2 \\
Carbohydrate & 0.9 & 0.4 & 0.6 & 0.5 & 0.9 & 0.5 \\
Ash & 3.0 & 0.6 & 3.0 & 0.6 & 3.0 & 0.6 \\
Sum & 100.0 & & 100.0 & & 100.0 & \\
Dry matter \% & 49.6 & 2.4 & 50.3 & 2.9 & 50.7 & 2.2 \\
\hline
\end{tabular}


Table 4. Calculation of the energy cost of transport (COT) after long term swimming. The energy consumption from female yellow eels was calculated from the oxygen consumption based on the oxycaloric equivalent of fat. In experiment I 5 eels swam about 3,000-km during 3 months at $0.5 \mathrm{BL} / \mathrm{s}$. In experiment II 11 eels swam about $5,600-\mathrm{km}$ during a period of 6 months at the same speed.

\begin{tabular}{|c|c|c|c|c|c|c|}
\hline & Experiment I & \multirow{4}{*}{$\begin{array}{l}\text { Speed } \\
\mathrm{km} / \mathrm{d} \\
31.41 \\
\end{array}$} & \multirow{4}{*}{$\begin{array}{c}3 \text { Months } \\
\mathrm{COT} \\
\mathrm{mgO}_{2} / \mathrm{km} \\
28.20\end{array}$} & \multirow{3}{*}{$\begin{array}{c}\text { Distance } 2980-\mathrm{km} \\
\mathrm{COT} \\
\mathrm{J} / \mathrm{km}\end{array}$} & & \\
\hline \multirow{3}{*}{$\begin{array}{l}\text { Length } \\
\text { M } \\
0.73\end{array}$} & \multirow{3}{*}{$\begin{array}{c}\text { Mean } \mathrm{VO}_{2} \\
\left(\mathrm{mgO}_{2} / \mathrm{kg} / \mathrm{h}\right) \\
36.90\end{array}$} & & & & \multicolumn{2}{|l|}{ Fat use } \\
\hline & & & & & $\mathrm{mg} / \mathrm{km}$ & $\mathrm{g} / 6000 \mathrm{~km}$ \\
\hline & & & & 386.88 & 9.79 & 58.77 \\
\hline & Experiment II & & 6 Months & Distance 5580-km & & \\
\hline Length & Mean $\mathrm{VO}_{2}$ & Speed & COT & COT & Fat use & \\
\hline $\mathrm{M}$ & $\left(\mathrm{mgO}_{2} / \mathrm{kg} / \mathrm{h}\right)$ & $\mathrm{km} / \mathrm{d}$ & $\mathrm{mgO}_{2} / \mathrm{km}$ & $\mathrm{J} / \mathrm{km}$ & $\mathrm{mg} / \mathrm{km}$ & $\mathrm{g} / 6000 \mathrm{~km}$ \\
\hline 0.75 & 42.26 & 32.27 & 31.43 & 431.21 & 10.92 & 65.50 \\
\hline
\end{tabular}

predictions differ in part: propeller efficiency of undulatory swimming decreases linearly as the rearward speed of the body wave increases relative to the swimming speed, and it is independent of the frequency and the amplitude of the body wave. Given that the swimming kinematics of trout and eel mainly differ in the amplitude envelope of their body wave, but have a similar range of body wave speeds [85], it is unlikely that kinematical differences between trout and eel can explain the difference in their overall metabolic efficiency.

The combined effect of propeller shape and motion on performance can be studied by visualizing the flow generated by anguilliform and carangiform swimmers. The ratio of forward to total momentum of the entire wake provides the mean propeller efficiency over a complete tail beat. This approach, whether using experimental or computational flow fields, requires the quantification of the three-dimensional flow in the complete wake, which so far has not been done. The currently available 2-dimensional slices through the wake suggest that eels generate considerable lateral momentum, which does not contribute to the forward motion and therefore reduces efficiency [41,74]. Tytell estimated a hydrodynamic efficiency of 0.5 to possibly up to 0.87 [74]. Equivalent estimates for carangiform fish are reported in the range from 0.74 to 0.97 [21, 41, 44]. These values suggest that trout has a higher propeller efficiency than eel, which does not to explain the higher overall metabolic efficiency of eels. Efficiency is also inversely related to thrust $[18,35]$. However, a $25 \%$ difference in swimming speed is insufficient to explain a fourfold difference in efficiency. So, the currently existing evidence on the hydrodynamics of undulatory swimming contradicts rather than explains the high swimming efficiency of eels.

\section{Muscle performance}

The efficiency with which a muscle converts chemical energy into mechanical work is important in prolonged aerobic locomotion, such as migration. Cruising is characterized by cyclic contractions at a well-defined frequency. Swimming speed depends linearly on tail beat frequency, and tail beat frequency corresponds to contraction frequency. The mechanical efficiency of muscle contractions depends on contraction speed in a non-linear fashion. This relationship can be predicted from Hill's model of muscle contractions [39] and has also been documented in fish swimming muscles [16]. There is a narrow range of contraction frequencies over which efficiency remains high. At contraction frequencies above and below this range, efficiency drops off progressively [16, 39]. McMahon [16] calculations show that maximum efficiency occurs at a contraction speed at $13 \%$ of the maximum contraction speed of the muscle, which is slightly lower speed than the speed at maximum power. To swim at maximum muscle efficiency, the fish should maintain a tail beat frequency that allows the muscle to contract at this optimal speed. If we take the contraction frequency that maximizes power as a first approximation of the contraction speed that maximizes efficiency, we can compare eel aerobic swimming muscles to those of trout. Eel muscles deliver peak power at much lower contraction frequencies $\left(0.5\right.$ to $0.8 \mathrm{~Hz}$ in silver eel; measured at $14^{\circ} \mathrm{C}$; [27]) than the muscles of trout ( 2 to $3 \mathrm{~Hz}$, measured at $11^{\circ} \mathrm{C}$ ) The swimming speeds that correspond to these contraction frequencies are $0.5 \mathrm{BL} / \mathrm{s}$ for eel and 0.4 to $1.0 \mathrm{BL} / \mathrm{s}$ for trout $[88,89]$. These values confirm that in our experiments both eel and trout were swimming close to their optimal swimming speed, and hence the much higher COT of trout is probably not due to the trout having been 
forced to swim under considerably suboptimal conditions for its swimming muscles.

At the low speeds used in this study, the eels will recruit only the posterior red muscle to swim continuously. As demonstrated in the work of Gillis [30] muscle fiber type recruitment was clearly dependent upon swimming speed. A pattern of 'posterior-toanterior' recruitment within a fiber type was observed as eels increased their swimming speed [30]. For example, eels typically used mainly posteriorly located red muscle (at 0.75 and $0.6 \mathrm{~L}$ ) to power slow-speed swimming, but would then additionally recruit more anteriorly located red muscle (at 0.45 and $0.3 \mathrm{~L}$ ) to swim at the higher speeds [30]. This unusual muscle activation pattern and kinematics may explain the low COT in eels compared with trout, in which most of the red muscle on each side of the body is stimulated during a tail-beat cycle assuming that the European and American eels are similar in this regard. In contradiction to this theory/ hypothesis of Gillis [30] to explain the low swimming efficiency of eel by recruitment patterns of muscle, Wardle et al. [87] have shown that the muscle activity pattern (\% time active during one tail beat cycle) does not differ substantially between different undulatory swimmers. Wardle's values for eel agree with those mentioned by Gillis [30]. Compared with trout and other fish, recruitment in eel is certainly not less by a factor of 2 to 4 . Hence it is not likely that more posterior muscle recruitment in eel can explain the many-fold difference in efficiency between eel and trout.

\section{Metabolism}

Overall metabolic efficiency is also influenced by the efficiency of the respiration and energy-conversion processes. The whole-organism locomotory performance is determined by its metabolic machinery, bringing us to the whole-body oxygen consumption (Routine Metabolic Rate) of the animal. In this study, we found a RMR of $29.55 \pm 4.2 \mathrm{ml} \mathrm{O}_{2} \mathrm{~kg}^{-1} \mathrm{~h}^{-1}$, which corresponds to $42.21 \pm 6.0 \mathrm{mg} \mathrm{O}_{2} \mathrm{~kg}^{-1} \mathrm{~h}^{-1}$. This value is similar to values reported in literature: $35 \mathrm{mg} \mathrm{kg}^{-1} \mathrm{~h}^{-1}$ (for the same-size animals at $\left.18^{\circ} \mathrm{C},[20,38]\right)$ for eel and also the routine metabolic rate (RMR) measurements of other fish species [92]. Hence, we may conclude that, based on metabolic rate comparisons with other fish species, the mitochondrial capacity remains the same. However, in the wild, eel do not migrate at the surface but in the deep sea: a migrating eel has been photographed at the Bahamas at a depth of 2,000 $\mathrm{m}$ [57]. There, they experience considerably larger pressures that might further increase metabolic efficiency at the mitochondrial level by increasing the efficiency of their oxidative phosphorylation [70]. In a laboratory study, exposing eels for 21 days at $10.1 \mathrm{MPa}$ hydrostatic pressure, Theron et al. [70] demonstrated that the ADP/O ratios, calculated from mitochondrial respiration measurements, were significantly increased. Eels actually performing the migration will not only experience higher pressures, but also lower temperatures, which will also affect their efficiency. Furthermore, eels might adapt their migratory route to take advantage of favorable sea currents, which would further reduce the energy requirements. However, with the migratory routes unknown, nothing can be said about the possible energy savings from pressure, temperature and seacurrent effects.

\section{Energy requirements for migration and reproduction}

Eels have a fat content of $10-28 \%$ with a mean of $20 \%[66,67]$, which is obviously the predominant energy store. Van den Thillart [75] calculated that $60 \%$ of the total fat reserve of silver eels is required for swimming. Animals with fat percentages of less than $13 \%$ fat would not be able to swim $6000-\mathrm{km}$. The question is how much fat is required for reproduction e. g. incorporation in the eggs. To calculate this we used characteristics of an eight year old female silver eel F9FE from Lake Grevelingen which was treated with 23 weekly injections carp pituitary extract [47]. At a weight of $1044 \mathrm{~g}(114 \%$, GSI $=45.6 \%)$ she was handstripped and eggs were fertilized. About 1500 eggs showed embryonic formation. $0.1 \mathrm{~g}$ gonad sample contained on average 282 eggs ( $n=6$ counts). Estimation of the total amount of eggs by multiplying with gonadal weight $476 \mathrm{~g}$ provides 1.34 million eggs. Calculation of the weight from one oocyte gives $0.355 \mathrm{mg}$. The diameter of an egg with a single fat droplet is on average $800 \mu \mathrm{m}$ [47]. Calculation of the volume gives $0.268 \mathrm{~mm}^{3}$. The diameter of a single fat droplet is on average $343 \mu \mathrm{m}$ [47]. Calculation of the volume gives $0.0211 \mathrm{~mm}^{3}$. The volume amount of water calculated by difference in volume of stage 7 vs a stage 0 egg which gives $0.22 \mathrm{~mm}^{3}$. This would represent $0.22 \mathrm{mg}$ and $82 \%$ of the stage $7 \mathrm{egg}$. Fat represented in a single egg would be $8 \%$ or about $0.06 \mathrm{mg}$; multiplying this with the total amount of eggs gives $80.5 \mathrm{~g}$ fat. This represents $36.6 \%$ of the total fat reserves and $7.7 \%$ of the animal. Thus, it can be concluded that $60 \%$ of the total fat reserves is used for swimming, $36.6 \%$ for incorporation in eggs; together $96.6 \%$. At least $13 \%$ is necessary for swimming which was found independent of size. On average $7.7 \%$ is incorporated in eggs indicating that silver eels should have a fat percentage of $20.7 \%$ to be able to migrate and reproduce success-fully. 


\section{EFFECTS OF SWIMMING ON MATURATION}

When eels migrate to the ocean in autumn, there is a limited development of the gonads up to a Gonadosomatic Index (GSI) of 1-2. If we keep these animals in aquaria, there is no further development of the gonads; even regression is often observed [25]. So the external environmental trigger for gonad maturation is lacking. Dufour [24] demonstrated for European eel in the silver stage, that there is a prepubertal blockage at the neuroendocrine level. There is a deficiency of gonadotropin releasing hormone $(\mathrm{GnRH})$ at the level of the pituitary, and also an inhibition by dopamine. Both factors could be responsible for inhibited production and release of gonadotropin (GTH) by the pituitary, resulting in an immature gonad. This led to the hypothesis that sexual immaturity in silver eels is caused by a dual blockage, which is situated at the level of the hypothalamo-pituitary axis in the brain. The endocrinological mechanism by which this dual blockage is abolished is not yet clear. For artificial maturation European eels must be weekly injected with CPE (carp pituitary extract) for 3-5 months $[53,54]$. This lengthy procedure is due to the heavy blockage and prepubertal stage of the silver eels. During artificial maturation the GSI values of mature female eels increase from 1-2 to 40-70 (references vide [81]). As silver eels leave the European West Coast in a prepubertal stage, maturation must develop on the way to, or at the spawning grounds. Therefore it is likely that maturation and development of the gonads is triggered by external or internal factors during their $6,000-\mathrm{km}$ migration to the Sargasso Sea.

It is not known which environmental factors can induce final maturation. For the maturation of migrating silver eel several environmental stimuli were suggested, including temperature [10], light, salinity [46] and water pressure [29]. The latter factor is based on one observation of a migrating eel with swollen belly at the Bahamas at 2000-m depth [57]. The first three environmental factors (temperature, light, and salinity), did not show a clear effect on the hypothalamo-pituitary-gonad axis $[10,46]$. Water pressure has been investigated in laboratory- $[60,61]$ as well as fieldstudies [23]. In high pressure laboratory studies with eel at respectively $25[46]$ and 110 atmosphere [60,61], no physiological changes were observed in the metabolism and no maturation of the gonads was observed. This was even the case after long term exposure to highpressure of one month [61], or 4 months [46]. In one study, stimulation of the HPG-axis was recorded. In this field-study[23], cages with silver eel were sunk in the Mediterranean Sea at a depth of $450 \mathrm{~m}$, corresponding to $45 \mathrm{Atm}$. A slight ovarian development was observed: a GSI of 1.56 in the control group compared to a GSI of 2.18 in the pressure exposed group. But the most remarkable change was the observation that the pituitary gonadotropin content increased by a factor 27 compared to the control group [23]. Remarkably, exercise has never been investigated as a potential stimulating factor. However, major physiological and endocrinological changes are the result of exercise in catadromic and anadromic fish species [62]. As European eels are supposed to swim 5,000-6,000-km to their spawning grounds we hypothesized that the effort itself may trigger the onset of maturation. A possible mechanism might be the increase of cortisol levels during exercise, which in turn may sensitize the pituitary for GnRH and release the inhibition by dopamine.

\section{Swim trials}

The ovaries of silver eels show oocytes in the first developmental stages [1] after transformation of the oogonia. Further progression requires incorporation of lipid droplets (stage 3) and vitellogenin. Although separated in other fish species, these two processes occur simultaneously in artificially matured Japanese eel [1] and European eel [47], which suggests an unnatural situation. Untreated silver eels are in a prepubertal stage, still far from sexual maturity $[22,24,34]$ and remain as such when kept resting in aquaria. Further sexual development of silver eel appears to be blocked by dopaminergic inhibition of hypothalamus and pituitary resulting in insufficient FSH and LH levels [24]. This blockage is likely required in order to allow the long spawning migration. Obviously there must be natural conditions that lead to release of this blockage. As European eels have to swim about 6000$\mathrm{km}$ to reach their spawning site, we hypothesize that swimming is the crucial trigger for releasing the dopaminergic inhibition.

Studies on the interaction between migration and maturation are scarce, which is surprising since especially migrant fish are often commercially interesting but difficult to reproduce in captivity. Exercise has never been thoroughly investigated as a stimulating factor for maturation in fish. Recently, Van Ginneken et al. [82] observed increased oocyte diameters in 3 year old hatchery eels after swimming 5,500-km. Significant higher levels of pituitary LH and plasma estradiol were found in the swim group as compared to the controls, also the oocyte diameter was increased. Those results indicate that long term swimming had an effect on maturation. Recently, we found indications that older eels have a higher capacity to incorporate fat from the muscle in the oocytes. In thirteen hormone-treated eels, we found a negative correlation between age with the amount of fat in muscles, and a positive correlation 
between age and the amount of incorporated fat in the gonads. This result indicates an increased capacity of older eels to incorporate fat in the gonads. This finding was confirmed by Durif et al. [26] who found positive correlations between age with condition factor, liver weight and vitellogenin level. Thus older eels have higher energy stores, and have a more efficient vitellogenesis. This is further supported by recent results showing that older eels require a shorter hormonal treatment to mature.

In a recent study, eels from Lake Balaton (Hungary) were subjected to a swimming period of one, two or six weeks. Most eels were silver and 13-21 years old. Changes in morphometrical parameters and developmental characteristics of the oocytes were determined (Table 5). Already after one week of swimming, the gonadal mass increased and oocytes became larger with large numbers of lipid droplets. After two and six weeks of swimming we found in addition significant enlargement of the eyes (Figure 7), which is a sign of sexual maturation. Continuous swimming at $0.5 \mathrm{BL} / \mathrm{s}$ resulted in an increase of the eye index (EI), which was apparent already after two weeks and occurred in all eels exposed to the swim trial. In contrast no change could be observed in the EI of the rest groups, indicating that neither waiting nor starvation could not have caused this. The observed changes appeared even stronger after six weeks of swimming. As increase of EI is connected with progression of sexual maturation, these observations clearly suggest that swimming induces maturation. The mean eye index of all the eels at arrival was $8.2 \pm 3.0$, corresponding with $59 \%$ silver eels. The degree of silvering and oocyte development was positively correlated with size for all parameters. This observation of silver eels in Lake Balaton contradicts Bíró [8], who stated that in Lake Balaton eels never metamorphose into silver eels. Already in the control group some silver eels were in migrant SI stage 5. These eels had a GSI $>1$ and gonads with some stage 3 oocytes although with few lipid droplets. Surprisingly, the migrant SI stage 4 [25] was not represented at all, not before nor after the swim experiments. This stage is characterized with elongated pectoral fins, however no changes of the pectoral fins were observed due to swimming. In field studies it was found that downstream silver eels have longer pectoral fins, from which was concluded that swimming likely causes the fins to grow [25,69]. As in our swim trials no change in fin length occurred, we must conclude that the increase in fin size during down stream migration must be due to other factors than swimming. However, swimming did result in other silver parameters like eye size and GSI

After six weeks of swimming, changes were much more pronounced than after two weeks of swimming,
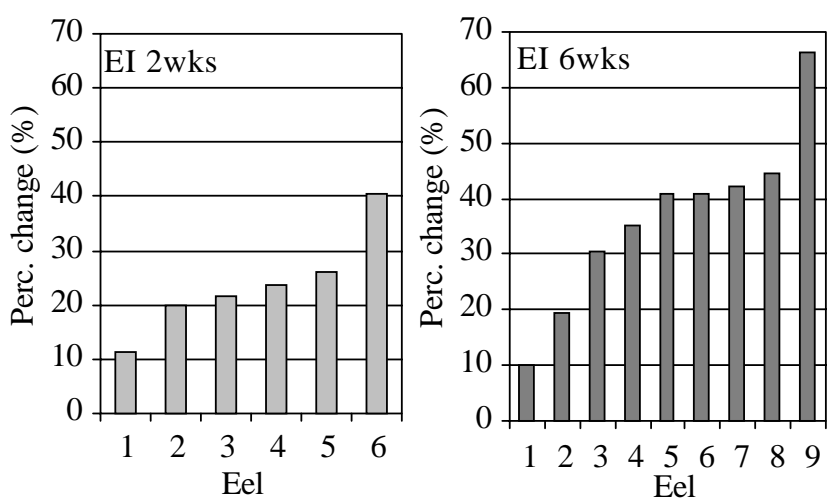

Fig. 7. Swimming induced changes of eye index (EI). Individual measurements are expressed in $(\%)$ increase of the Eye Index (EI). Eels swam for 2 and 6 weeks at $0.5 \mathrm{BL} / \mathrm{s}$. The EI was significantly increased after both periods.

Table 5. Swimming induced changes. Eels from Lake Balaton (13-21 yrs old) were swum at 0.5 BL/s for up to 6 weeks. Bold figures in upper part indicate pair wise differences (pre- vs. post swim). Bold figures in lower part indicate significant differences with respect to the controls.

\begin{tabular}{lrrrrr}
\hline & & \multicolumn{2}{c}{2 Weeks } & \multicolumn{2}{c}{6 Weeks } \\
& Control & Pre-swim & Post-swim & Pre-swim & Post-swim \\
\hline $\mathrm{N}$ & 10 & 6 & 6 & 9 & 9 \\
Body length $(\mathrm{cm})$ & 59 & 62 & 62 & 63 & 63 \\
Body weight $(\mathrm{g})$ & 267 & 347 & $\mathbf{3 3 3}$ & 429 & $\mathbf{3 6 6}$ \\
Condition factor & 0.13 & 0.14 & 0.14 & 0.16 & $\mathbf{0 . 1 4}$ \\
Eye index & 6.2 & 8.3 & $\mathbf{1 0 . 3}$ & 6.9 & $\mathbf{9 . 1}$ \\
& & & & & \\
Gonado somatic index & 0.26 & & $\mathbf{0 . 7 4}$ & & $\mathbf{0 . 8}$ \\
Oocyte stage & 1.7 & & $\mathbf{2 . 4}$ & & $\mathbf{2 . 4}$ \\
Oocyte diameter $(\mu \mathrm{m})$ & 83 & & $\mathbf{1 3 6}$ & & $\mathbf{1 0 9}$ \\
\hline
\end{tabular}


both GSI and oocyte diameters were significantly higher. More than 50\% of the eels that had swum for two and six weeks had oocytes predominantly in stage 3 , while in contrast resting eels had no stage 3 oocytes at all (Figure 8 ). The lipid vesicle stage was observed only in eels that swam, also the number of eels with a progressed stage of development increased with the length of the swim period (Figure 9). Obviously the lipid deposition in the oocytes is enabled by the activated lipid mobilization required for the increased energy consumption during swimming. Oocytes in stage 3 show a high variation in numbers and diameter of lipid droplets, in other words in total lipid content. This increase of lipid content is typical for stage 3. During this stage no vitellogenin is incorporated, the oocytes almost double in size only due to fat deposition (Figure 10). It appears therefore that this process is a natural (and possibly also a) crucial step in oocyte maturation.

Recently, Van Ginneken et al. [82] simulated a complete migration of 5,500-km using 3 year old silver eels from the farm. Those eels were $71 \pm 4 \mathrm{~cm}$ long and weighed $792 \pm 104 \mathrm{~g}$, bigger than the ones used in the Balaton study. Significantly higher levels of pituitary LH were found in the swim group as compared to the controls, also the oocyte diameter was increased. These results indicate that long term swimming had an effect on maturation of younger farmed eels. However, in this study no changes in EI and GSI were found. Thus,

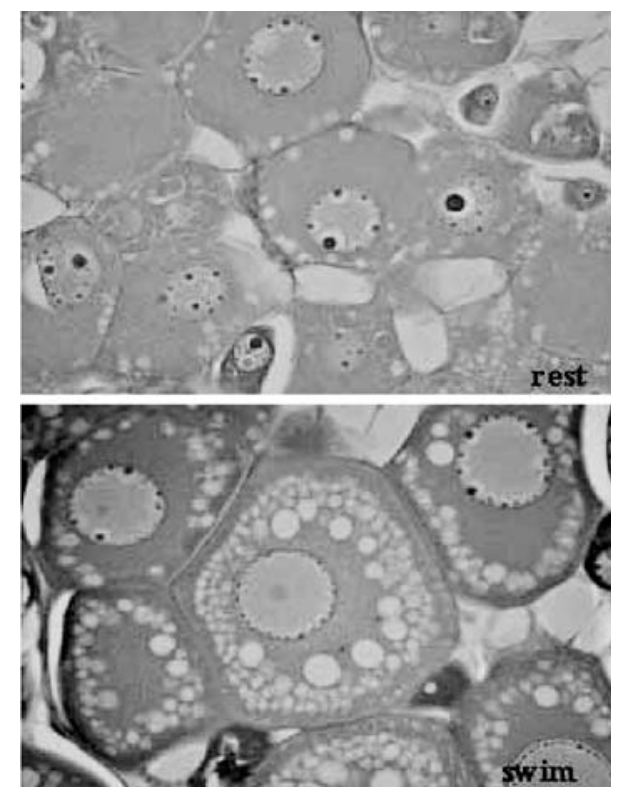

Fig. 8. Typical pictures of coupes stained with HE form a rest group and from a group that swam for a week. Magnification 40x. In the swim group significantly larger oocytes, larger nuclei and a higher number of nucleoli were found compared to the rest group. despite the increased hormone levels, the gonads did not develop. The more explicit changes in the Balaton study, already after two weeks of swimming, might be explained by the difference in age. The hatchery eels were young ( 3 years) while the Lake Balaton eels were much older (13 to 21 years).

Information about GSIs of silver eels caught in the open ocean is scarce. In the literature only two cases were described where silver eels were caught during their journey to their spawning grounds in the Sargasso Sea. One female eel was caught near the Azores and had a GSI of 9.8 [6], another was caught near the Faroe Islands and had a GSI of 2.9 [28]. This GSI is far away

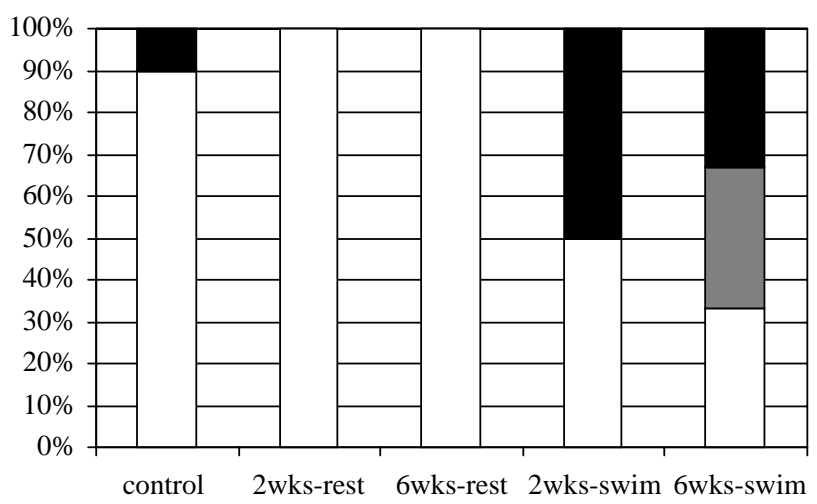

Fig. 9. Distribution of oocyte stages in eels of control, rest and swim groups after 2 and 6 weeks swimming. White: stage 1 oocytes. Black: stage 3 oocytes. Grey: stage $2+3$ oocytes. The swim groups had significantly more eels with further developed oocytes.

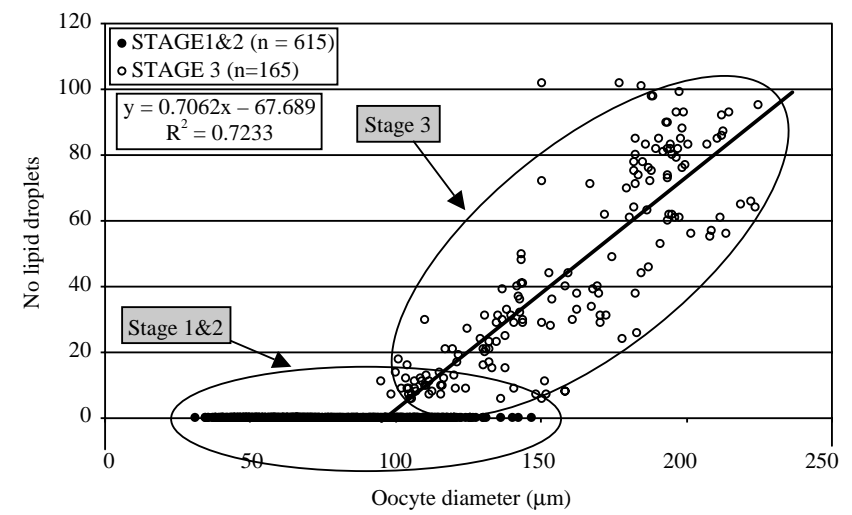

Fig. 10. Relationship between oocyte diameter and lipid deposition in the oocytes. Depicted are the relation between the oocyte diameter and the number of lipid droplets. Only eels that had swum had stage 3 oocytes, which are characterized by fat droplets. Those eels had oocytes with a diameter of $154 \pm 34$ £gm containing $38.4 \pm 26.8$ fat droplets with a diameter of 10 . $4 \pm 2.5 \mu \mathrm{m}$. Significant positive correlations were found between oocyte diameter and the number of lipid droplets $(\mathrm{P}<$ 0.001). 
from the value observed for hormone treated sexually mature females $[47,81]$. The field data indicate that final maturation may develop at the end of the journey and not during. Experimental data show that swimming plays a major role in the natural oocyte development, and may as well sensitize eels for final maturation.

\section{CONCLUSIONS}

Our respiratory measurements as well as the carcass analyses suggest that eels have a much higher metabolic efficiency than trout. In eel, the COT values obtained from oxygen consumption data and carcass analyses are 0.42 and $0.62 \mathrm{~kJ} / \mathrm{kg} / \mathrm{km}$, respectively, whereas trout has a much higher COT value of around 2 . $7 \mathrm{~kJ} / \mathrm{kg} / \mathrm{km}$. The COT in trout matches the value measured by Webb [88], and is similar to other salmonids [14] and many adult fish species [85]. This means that eel swim 4 to 6 times more efficiently than other fish species, even across swimming styles. European eel is able to swim 5,500-km, a distance corresponding to their supposed spawning area in the Sargasso Sea at a remarkably high swimming efficiency and at low energy costs. So, we can conclude that healthy well fed eels are able to reach the Sargasso leaving enough reserves for reproduction.

Swim fitness and the ability to migrate are negatively influenced by infections with $A$. crassus. High infection levels result in a damaged swim bladder; both the parasite weight as well as the damaged swim bladder interferes with swim performance. Both swim-bladders with high parasite weight causes as well as damaged swim bladders have reduced volume causing negative buoyancy. Thus in both cases the chance to reach the spawning site is very low.

There is strong evidence that swimming triggers silvering and early maturation. Long term swimming with young eels resulted in increased hormone levels, with only small effects on gonad development. On the other hand several weeks of swimming were sufficient for much older Balaton eels to increase eye index and to cause extensive lipid deposition in the oocytes. Therefore it is obvious that swimming plays an crucial role in natural maturation of eel.

\section{AKNOWLEDGEMENTS}

Funded by grants from EU (EELREP \#Q5RS2001-01836), and STW- Dutch technology foundation (LBI66.4199).

\section{REFERENCES}

1. Adachi, S., Ijiri, S., Kazeto, Y., and Yamauchi, K.,
"Oogenesis in the Japanese Eel, Anguilla Japonica," In Aida, K., Tsukamoto, K., and Yamauchi, K. (Eds.), Eel Biology, Springer, pp. 502-518 (2003).

2. Antunes, C. and Tesch, F.W., "Eel Larvae (Anguilla anguilla L.) Caught by RV "Heincke" at the European Continent Slope in Autumn 1991," Ecology of Freshwater Fish, Vol. 6, pp. 50-52 (1997).

3. Avise, J.C., Helfman, G.S., Saunders, N.C., and Hales, L.S., "Mitochondrial DNA Differentiation in North Atlantic Eels: Population Genetics Consequences of an Unusual Life History Pattern," Proceedings of the National Academy of Sciences USA, Vol. 83, pp. 43504354 (1986).

4. Avise, J.C., Nelson, W.S., Arnold, J., Koehn, R.K., Williams, G.C., and Thorsteinsson, V., "The Evolutionary Genetic Status of Icelandic Eels," Evolution, Vol. 44, 1254-1262 (1990).

5. Barni, S., Bernocchi, G., and Gerzeli, G., "Morphohistochemical Changes during the Life Cycle of the European Eel," Tissue \& Cell, Vol. 17, pp. 97-109 (1985).

6. Bast, H.D. and Klinkhardt, M.B., "Fang Eines Silberaales (Anguilla anguilla (L. 1758)) im Iberischen Becken (Nordostatlantik) (Teleostei: Anguillidae)," Zoologischer Anzeiger, Vol. 221, pp. 386-398 (1988).

7. Beregi, A., Molnár, K., Békési, L., and Székely, C.S., "Radiodiagnostic Method for Studying Swimbladder Inflammation Caused by Anguillicola crassus (Nematoda: Dracunculoidea)," Diseases of Aquatic Organisms, Vol. 34, pp. 155-160 (1998).

8. Bíró, P., "Die Geschichte des Aals (Anguilla anguilla L.) im Plattensee (Balaton)," Österreichs Fischerei, Vol. 45, pp. 197-207 (1992).

9. Blazka, P., Volf, M., and Ceplea, M., "A New Type of Respirometer for Determination of the Metabolism of Fish in an Active State," Physiol Bohemoslov, Vol. 9, pp. 553-560 (1960).

10. Boëtius, I. and Boëtius, J., "Studies in the European Eel, Anguilla anguilla. Experimental Induction of the Male Sexual Cycle, Its Relation to Temperature and Other Factors," Meddelseler fra Danmarks Fiskeri- og Havundersogelser, Vol. 4, pp. 339-405 (1967).

11. Bone, Q., Marshall, N.B., and Blaxter, J.H., Biology of Fishes, Chapman \& Hall, London (1995).

12. Boon, J.H., Lokin, C.J.A., Ceusters, R., and Ollevier, F., "Some Properties of the Blood of European Eel (Anguilla anguilla) and the Possible Relationship with Anguillicola Crassus Infestations," Aquaculture, Vol. 76, pp. 203208 (1989)

13. Brafield, A.E. and Llewellyn, M.J., Animal Energetics, Glasgow, Blackie (1982).

14. Brett, J.R., "The Respiratory Metabolism and Swimming Performance of Young Sokeye Salmon," Journal of the Fisheries Research Board of Canada, Vol. 21, pp. 1183-1226 (1964). 
15. Comparini, A. and Rodino, E., "Electrophoretic Evidence for Two Species of Anguilla Leptocephali in the Sargasso Sea," Nature, Vol. 287, pp. 435-437 (1980).

16. Curtin N.A. and Woledge R., "Efficiency of Energy Conversion during Sinusoidal Movement of Red Muscle Fibres from the Dogfish Scyliorhinus canicula," Journal of Experimental Biology, Vol. 185, pp. 195-206 (1993).

17. D'Ancona, U. and Tucker, D.W., "Old and New Solutions to the Eel Problem," Nature, Vol. 183, pp. 1405-1406 (1959).

18. Daniel, T.L. "Efficiency in Aquatic Locomotion: Limitations from Single Cells to Animals," In Blake, R.W. (Eds), Efficiency and Economy in Animal Physiology, Cambridge University Press, Cambridge, U.K., pp. 8395 (1991).

19. Deelder, C.L. and Tucker, D.W., "The Atlantic Eel Problem," Nature, Vol. 185, pp. 589-592 (1960).

20. Degani, G., Gallagher, M.L., and Metzler, A., "The Influence of Body Size and Temperature on Oxygen Consumption of the European Eel, Anguilla anguilla," Journal of Fish Biology, Vol. 34, pp. 19-24 (1989).

21. Drucker, E.G. and Lauder, G.V., "Locomotor Function of the Dorsal Fin in Teleost Fishes: Experimental Analysis of Wake Forces in Sunfish," Journal of Experimental Biology, Vol. 204, pp. 2943-2958 (2001).

22. Dufour, S., "Neuroendocrinologie de la Reproduction de l'anguille: de la Recherche Fondamentale Aux Problemes Applique," Bulletin Francais de la Pêche et de la Pisciculture, Vol. 335, pp. 187-211 (1994).

23. Dufour, S. and Fontaine, Y.A., "La Migration de Reproduction de l' anguille Europeenne (Anguilla anguilla L.): un rôle Probable de la Pression Hydrostatique Dans la Stimulation de la Fonction Gonadotrope," Bulletin de la Société Zoologique de France, Vol. 110, pp. 291-299 (1985).

24. Dufour, S., Burzawa-Gerard, E., Le Belle, N., Sbaihi, M., and Vidal, B., "Reproductive Endocrinology of the European Eel, Anguilla anguilla," In Aida, K., Tsukamoto, K., Yamauchi, K. (Eds.), Eel Biology, Springer, pp. 373-386 (2003).

25. Durif, C., Dufour, S., and Elie, P., "The Silvering Process of the Eel: A New Classification from the Yellow Resident Stage to the Silver Migrating Stage," Journal of Fish Biology, Vol. 66, pp. 1-19 (2005).

26. Durif, C.M.F., Dufour, S., and Elie, P., "Impact of Silvering Stage, Age, Body Size and Condition on the Reproductive Potential of the European Eel," Marine Ecology Progress Series, Vol. 327, pp. 171-181 (2006).

27. Ellerby, D.J., Spierts, I.L.Y., Altringham, J.D., "Slow Muscle Power Output of Yellow-and Silver-Phase European Eels (Anguilla anguilla L.): Changes in Muscle Performance Prior to Migration," The Journal of Experimental Biology, Vol. 204, pp. 1369-1379 (2001).

28. Ernst, P., "Catch of an Eel (Anguilla anguilla) Northeast of the Faroe Islands," Annales Biologiques, Vol. 32, p. 175 (1977).

29. Fontaine, Y.A., "Adaptations Versus Accomodations: Some Neuroendocrine Aspects in Teleost Fish," Fish Physiology and Biochemistry, Vol. 11, pp. 147-154 (1993).

30. Gillis, G.B., "Neuromuscular Control of Anguilliform Locomotion: Patterns of Red and White Muscle Activity during Swimming in the American Eel Anguilla rostrata," Journal of Experimental Biology, Vol. 201, pp. 3245-3256 (1998).

31. Gutleb, A.C., Appelman, J., Bronkhorst, M.C., van den Berg, J.H.J., Spenkelink, A., Brouwer, A., and Murk, A. J., "Delayed Effects of Pre- and Early-Life Time Exposure to Polychlorinated Biphenyls on Tadpoles of Two Amphibian Species (Xenopus Laevis and Rana Temporaria)," Environmental Toxicology and Pharmacology, Vol. 8, pp. 1-14 (1999).

32. Höglund, J., Andersson, J., and Härdig, J., "Hamaetological Responses in the European Eel, Anguilla anguilla L., to Sublethal Infestation by Anguillicola crassus in a Thermal Effluent of the Swedish Baltic," Journal of Fish Diseases, Vol. 15, pp. 507-514 (1992).

33. Jellyman, D., "Review of the Marine Life History of Austral-Asian Temperate Species of Anguilla," American Fisheries Society Symposium, Vol. 1, pp. 276-285 (1987).

34. Larsen, L.O. and Dufour, S., "Growth, Reproduction and Death in Lampreys and Eels," In Rankin, J.C. and Jensen, F.B. (Eds.), Fish Ecophysiology, Chapman and Hall, London, pp. 72-104 (1993).

35. Lighthill, M.J., "Large-Amplitude Elongated-Body Theory of Fish Locomotion," Proceedings of Royal Society of London, Vol. 179, pp. 125-138 (1971).

36. McCleave, J.D., "Swimming Performance of European Eel (Anguilla anguilla L.) Elvers," Journal of Fish Biology, Vol. 16, pp. 445-452 (1980).

37. McCleave, J.D., Kleckner, R.C., and Castonguay, M., "Reproductive Sympatry of American en European Eels and Implications for Migration and Taxonomy," American Fisheries Society Symposium, Vol. 1, pp. 286-297 (1987).

38. McKenzie, D.J., Piraccini, G., Piccolella, M., Steffensen, J.F., Bolis, C.L., and Taylor, E.W., "Effects of Dietary Fatty acid Composition on Metabolic Rate and Responses to Hypoxia in the European Eel (Anguilla anguilla)," Fish Physiology and Biochemistry, Vol. 22, pp. 281-296 (2000).

39. McMahon, T.A., Muscles, Reflexes and Locomotion, Princeton University Press Princeton, USA (1984).

40. Molnár, K., Baska, F., Csaba, G.Y., Glávits, R., and Székely, C.S., "Pathological and Histopathological Studies of the Swimbladder of Eels Anguilla anguilla infected by Anguillicola crassus (Nematoda: Dracuncu- 
loidea)," Diseases of Aquatic Organisms, Vol. 15, pp. 41-50 (1993).

41. Müller, U.K., Smit, J., Stamhuis, E.J., and Videler, J.J., "How the Body Contributes to the Wake in Undulatory Fish Swimming: Flow Fields of a Swimming Eel (Anguilla anguilla)," Journal of Experimental Biology, Vol. 204, pp. 2751-2762 (2001).

42. Münderle, M., Sures, B., and Taraschewski, H., "Influence of Anguillicola crassus (Nematoda) and Ichthyophthirius multifiliis (Ciliophora) on Swimming Activity of European Eel Anguilla anguilla," DAO, Vol. 60, pp. 133-139 (2004).

43. Nagahama, Y., "Endocrine Regulation of Gametogenesis in Fish," International Journal of Developmental Biology, Vol. 38, pp. 217-229 (1994).

44. Nauen, J.C. and Lauder, G.V., "Hydrodynamics of Caudal Fin Locomotion by Chub Mackerel, Scomber japonicus (Scombridae)," Journal of Experimental Biology, Vol. 205, pp. 1709-1724 (2002).

45. Nieddu, M., Pichiri, G., Coni, P., Salvadori, S., Deiana, A.M., and Mezzanotte, R., "A Comparative Analysis of European and American Eel (Anguilla anguilla and Anguilla rostrata) Genomic DNA: 5S rDNA Polymorphism Permits the Distinction Between the Two Populations," Genome, Vol. 41, pp. 728-732 (1998).

46. Nilsson, L., Nyman, L., Westin, L., and Ornhagen, H., "Simulation of the Reproductive Migration of European Eels (Anguilla anguilla $(\mathrm{L}$.$) ) Through Manipulation of$ Some Environmental Factors under Hydrostatic Compression," Speculations in Science and Technology, Vol. 4, pp. 475-484 (1981).

47. Palstra, A.P., Cohen, E.G.H., Niemantsverdriet, P.R.W., van Ginneken, V.J.T., and van den Thillart, G.E.E.J.M., "Artificial Maturation and Reproduction of European Silver Eel: Development of Oocytes during Final Maturation," Aquaculture, Vol. 249, No. 1-4, pp. 533547 (2005).

48. Palstra, A.P., Heppener, D.F.M., van Ginneken, V.J.T., Székely, C., and van den Thillart, G.E.E.J.M., "Swim Efficiency and Reproductive Migration of Silver Eels Are Severely Impaired by the Swim-Bladder Parasite Anguillicola Crassus," In Palstra, A.P. (Eds), Energetic Requirements and Environmental Constraints of Reproductive Migration and Maturation of European Silver Eel (Anguilla Anguilla L.), University of Leiden, Leiden, The Netherlands (2006).

49. Palstra, A., Curiel, D., Fekkes, M., de Bakker, M., Székely, C., van Ginneken, V., van den Thillart, G., "Swimming Stimulates Oocyte Development in European Eel (Anguilla anguilla L.)," In Palstra, A.P. (Eds), Energetic Requirements and Environmental Constraints of Reproductive Migration and Maturation of European Silver Eel (Anguilla Anguilla L.), University of Leiden, Leiden, The Netherlands (2006).
50. Palstra, A., van Ginneken and V., van den Thillart, G., "Swim Performance of European Silver Eels (Anguilla anguilla)," In Palstra, A.P. (Eds), Energetic Requirements and Environmental Constraints of Reproductive Migration and Maturation of European Silver Eel (Anguilla Anguilla L.), University of Leiden, Leiden, The Netherlands (2006).

51. Palstra, A.P., van Ginneken, V.J.T., Murk, A.J., van den Thillart, G.E.E.J.M., "Are Dioxin-Like Contaminants Responsible for the Eel (Anguilla anguilla) Drama?" Naturwissenschaften, Vol. 93, pp. 145-148 (2006).

52. Pankhurst, N.W. and Lythgoe, J.N., "Changes in Vision and Olfaction during Sexual Maturation in the European Eel Anguilla anguilla (L.)," Journal of Fish Biology, Vol. 23, pp. 229-240 (1983).

53. Pedersen, B.H., "Induced Sexual Maturation of the European Eel Anguilla anguilla and Fertilisation of the Eggs," Aquaculture, Vol. 224, pp. 323-338 (2003).

54. Pedersen, B.H., "Fertilisation of Eggs, Rate of Embryonic Development and Hatching Following Induced Maturation of the European Eel Anguilla anguilla," Aquaculture, Vol. 237, pp. 461-473 (2004).

55. Pocar, P., Brevini, T.A., Fischer, B., and Gandolfi, F., "The Impact of Endocrine Disruptors on Oocyte Competetence," Reproduction, Vol. 125, pp. 313-325 (2003).

56. Post, A. and Tesch, F.W., "Midwater Trawl Catches of Adolescent and Adult Anguilliform Fishes during the Sargasso Sea Eel Expedition 1979," Helgoländer Meeresuntersuchungen, Vol. 35, pp. 341-356 (1982).

57. Robins, C.R., Cohen, D.M., and Robins, C.H., "The Eels Anguilla and Histiobranchus, Photographed on the Floor of the Deep Atlantic in the Bahamas," Bulletin of Materials Sciences, Vol. 29, pp. 401-405 (1979).

58. Schmidt, J., "Breeding Places and Migration of the Eel," Nature, Vol. 111, pp. 51-54 (1923).

59. Schmidt-Nielsen, K., "Locomotion: Energy Cost of Swimming, Flying and Running," Science, Vol. 177, pp. 222-228 (1972).

60. Sebert, P. and Barthelemy, L., "Effects of High Hydrostatic Pressure per se, 101 atm on Eel Metabolism," Respiration Physiology, Vol. 62, pp. 349-357 (1985).

61. Simon, B., Sebert, P., and Barthelemy, L., "Effects of Long-Term Hydrostatic Pressure per se (101 ATA) on Eel Metabolism," Canadian Journal of Physiology and Pharmacology, Vol. 67,pp. 1247-1251 (1988).

62. Smith, C. L., The Inland Fishes of New York State NYS D.E.C., NewYork (1985).

63. Smith, L.S. and Newcomb, T.W., "A Modified Version of the Blazka Respirometer and Exercise Chamber for Large Fish," Journal of the Fisheries Research Board of Canada, Vol. 27, pp. 1321-1324 (1970).

64. Sprengel, G. and Lüchtenberg, H., "Infection by Endoparasites Reduces Maximum Swimming Speed of 
European Smelt Osmerus eperlanus and European Eel Anguilla anguila," Diseases of Aquatic Organisms, Vol. 11, pp. 31-35 (1991).

65. Stouthart, X.J.H.X., Huijbregts, M.A.J., Balm, P.H.M., Lock, R.A.C., and Wendelaar Bonga, S.E., "Endocrine Stress Response and Abnormal Development in Carp (Cyprinus Carpio) Larvae After Exposure of the Embryos to PCB 126," Fish Physiology and Biochemistry, Vol. 18, pp. 321-329 (1998).

66. Svedang, H. and Wickström, H., "Maturation Patters in Female European Eel: Age and Size at the Silver Eel Stage," Journal of Fish Biology, Vol. 48, pp. 342-51 (1997).

67. Svedäng, H. and Wickstrom, H., "Low Fat Contents in Female Silver Eels: Indications of Insufficient Energetic Stores for Migration and Gonadal Development," Journal of Fish Biology, Vol. 50, pp. 475-486 (1997).

68. Tagliavini, J., Harrison, I.J., and Gandolfi, G., "Discrimination between Anguilla anguilla and Anguilla rostrata by Polymerase Chain Reaction-Restriction Fragment Length Polymorphism Analysis," Journal of Fish Biology, Vol. 47, pp. 741-743 (1995).

69. Tesch, W.W., The Eel, Biology and Management of Anguilled Eels, Chapman \& Hall, London, (1977).

70. Theron, M., Guerrero, F., and Sébert, P., "Improvement in the Efficiency of Oxidative Phosphorylation in the Freshwater Eel Acclimated to 10.1 MPa Hydrostatic Pressure," Journal of Experimental Biology, Vol. 203, pp. 3019-3023 (2000).

71. Tsukamoto, K., "Discovery of the Spawning Area for Japanese Eel, Nature, Vol. 356, pp. 789-791 (1992).

72. Tucker, D.W., "A New Solution to the Atlantic Eel Problem," Nature, Vol. 183, pp. 495-501 (1959).

73. Tyler, C.R. and Sumpter, J.P., "Oocyte Growth and Development in Teleosts," Reviews in Fish Biology and Fisheries, Vol. 6, 287-318 (1996).

74. Tytell, E.D. and Lauder, G.V., "The Hydrodynamics of Eel Swimming. I. Wake Structure," Journal of Experimental Biology, Vol. 207, pp. 1825-1841 (2004).

75. van den Thillart, G., van Ginneken, V., Körner, F., Heijmans, R., van der Linden, R., and Gluvers, A., "Endurance Swimming of European Eel," Journal of Fish Biology, Vol. 65, pp. 1-7 (2004).

76. Van Dijk, P.L., Van den Thillart, G., Balm, P., and Wendelaar Bonga, S., "The Influence of Gradual Water Acidification on the Acid/Base Status and Plasma Hormone Levels in the Carp," Journal of Fish Biology, Vol. 42, pp. 661-671 (1993).

77. van Ginneken, V. and van den Thillart, G., "Eel Fat Stores are Enough to Reach the Sargasso," Nature, Vol. 403, pp. 156-157 (2000).

78. van Ginneken, V., Antonissen, E., Muller, U.K., Booms, R., Eding, E., Verreth, J., and van den Thillart, G., "Eel Migration to the Sargasso: Remarkably Hifg Swimming
Efficiency and Low Energy Costs," Journal of Experimental Biology, Vol. 208, pp. 1329-1335 (2005).

79. Van Ginneken, V., Ballieux, B., Willemze, R., Coldenhoff, K., Lentjes, E., Antonissen, E., Haenen, O., and van den Thillart, G., "Hematology Patterns of Migrating European Eels and the Role of EVEX Virus," Comparative Biochemistry and Physiology, Part C, Vol. 140, pp. 97-102 (2005).

80. Van Ginneken, V., Haenen, O., Coldenhoff, K., Willemze, R., Antonissen, E., van Tulden, P., Dijkstra, S., Wagenaar, F., and van den Thillart, G., "Presence of Eel Viruses in Eel Species from Various Geographic Regions," Bulletin of the European Association of Fish Pathologists, Vol. 24, No. 5, pp. 268-271 (2004).

81. van Ginneken, V., Vianen, G., Muusze, B., Palstra, A.P., Verschoor, L., Lugten, O., Onderwater, M., van Schie, S., Niemansteverdriet, P., van Heeswijk, R., Eding, E., and van den Thillart, G., "Gonadal Development and Spawning Behavior of Artificially-Matured European Eel (Anguilla anguilla L.)," Animal Biology, Vol. 55, pp. 203-218 (2005).

82. van Ginneken, V.J.T., Dufour, S., Sbaihi, M., Balm, P., Noorlander, K., de Bakker, M., Doornbos, J., Antonissen, E., Mayer, I., and van den Thillart, G., "A 5,500-km Swim Trial Stimulates Gonad Maturation in the European Eel (Anguilla anguilla L.)," In Simulated Migration of European eel (Anguilla anguilla, Linaeus 1758), $\mathrm{PhD}$ thesis, Wageningen University, Wageningen, The Netherlands (2006).

83. van Leeuwen, C. and Hermens, J., Risk Assessment of Chemicals: an Introduction. Kluwer Academic Pub., Dordrecht, The Netherlands (1995).

84. van Leeuwen, S.P.J., Traag, W.A., Hoogenboom, L.A. P., de Boer, J., "Dioxins, Furans and Dioxin-Like Pcbs in Wild, Farmed, Imported and Smoked Eel from the Netherlands," Organohalogen Compounds, Vol. 57, pp. 217-220 (2002).

85. Videler, J.J., Fish Swimming, Chapman \& Hall, London, Vol. 10, pp. 260 (1993).

86. Wallace, R.A. and Selman, K., "Cellular Dynamic Aspects of Oocyte Growth in Teleosts," American zoologist, Vol. 21, pp. 325-343 (1981).

87. Wardle, C.W., Videler, J.J., and Altringham, J.D., "Tuning in to Fish Swimming Waves: Body form, Swimming Mode and Muscle Function," Journal of Experimental Biology, Vol. 198, pp.1629-1636 (1995).

88. Webb, P.W., "The Swimming Energetics of Trout. 1. Thrust and Power at Cruising Speeds," Journal of Experimental Biology, Vol.55, pp. 489-520 (1971).

89. Webb, P.W., "The Swimming Energetics of Trout. II. Oxygen Consumption and Swimming Efficiency," Journal of Experimental Biolology, Vol. 55, pp. 521-540 (1971b).

90. Webb, P.W., "Hydrodynamics and Energetics of Fish 
Propulsion," Journal of the Fisheries Research Board of Canada, Vol. 190, pp. 77-105 (1975).

91. Williams, G.C. and Koehn, K., "Population Genetics of North Atlantic Catadromous Eels (Anguilla)," In Turner, B.J. (Eds), Evolutionary Genetics of Fishes, Plenum Press, New York, pp. 529-560 (1984).

92. Winberg, G.G., "Rate of Metabolism and Food Require- ments of Fishes," Fisheries Research Board of Canada Translation Series, Vol.194, pp. 202 (1956).

93. Wirth, T. and Bernatchez, L., "Genetic Evidence Against Panmixia in the European Eel," Nature, Vol. 409, pp. 1037-1040 (2001).

94. Wolf, K., Fish Viruses and Fish Viral Diseases. Cornell University Press, Ithaca, USA, p. 476 (1988). 